\begin{tabular}{|c|c|c|}
\hline Beitr. Ent. & Keltern & ISSN 0005-805X \\
\hline $\mathbf{5 7}(2007) 2$ & S. $263-275$ & 21.12 .2007 \\
\hline
\end{tabular}

\title{
Drywood termites in Dominican amber
}

\section{(Isoptera: Kalotermitidae)}

With 10 figures and 1 table

\author{
M. S. ENGEL and K. Krishna
}

\section{Summary}

The known fauna of Early Miocene (Burdigalian) drywood termites (Isoptera: Kalotermitidae) in amber from the Dominican Republic is revised. To the previously described Cryptotermes yamini KRISHNA \& BACCHUs, four species are added to the biota: Incisitermes peritus sp. n.; Glyptotermes paleoliberatus sp. n.; G. grimaldii sp. $\mathbf{n} . ;$ and Cryptotermes glaesarius sp. $\mathbf{n}$. The record of Incisitermes is the first in Dominican amber for the genus, the only other species being I. krishnai EMERson in latest Oligocene amber from Chiapas, Mexico (descriptive notes and new photographs of I. krishnai are appended). The species of Glyptotermes are the first New World and Tertiary fossils of the genus, the only other record being a species in Pleistocene copal from Africa.

\section{Resumen}

Se revisa la fauna de termitas de madera seca (Isoptera: Kalotermitidae) del Mioceno basal (Burdigaliano) presente en ámbar de la República Dominicana. Además de la previamente descrita Cryptotermes yamini KRISHNA y BaCchus, se añaden cuatro nuevas especies a la fauna: Incisitermes peritus sp. n.; Glyptotermes paleoliberatus sp. n.; G. grimaldii sp. n.; y Cryptotermes glaesarius sp. n. El registro de Incisitermes es el primero de este género en ámbar dominicano, siendo I. krishnai EMERson en ámbar del Oligoceno-Mioceno de Chiapas, México, la única otra especie conocida en ámbar (se incluyen notas descriptivas y fotografías nuevas de I. krishnai). Las especies de Glyptotermes son los primeros fósiles del género registrados para el Nuevo Mundo y el periodo Terciario, el único otro registro conocido es una especie en copal del Pleistoceno proveniente de África.

\section{Zusammenfassung}

Die bisher bekannte Trockenholztermiten-Fauna (Isoptera: Kalotermitidae) aus dem Dominikanischen Bernstein des Frühen Miozän (Burdigalian) wird revidiert. Dem früher beschriebenem Cryptotermes yamini Krishna \& BaCchus werden vier Arten hinzugefügt: Incisitermes peritus sp. n., Glyptotermes paleoliberatus sp. n., G. grimaldii sp. n. und Cryptotermes glaesarius sp. n. Der Fund von Incisitermes ist der erste für die Gattung im Dominikanischen Bernstein; die einzige andere Spezies, I. krishnai Emerson, stammt aus dem spätoligozänen Bernstein von Chiapas, Mexiko (deskriptive Anmerkungen und neue Photos von I. krishnai werden angefügt). Die Glyptotermes-Arten sind die ersten neuweltlichen und tertiären Fossilien der Gattung; der einzige andere Fund ist eine Art aus pleistozänem Kopal von Afrika.

\section{Keywords}

Isoptera, termite, Miocene, Tertiary, paleontology, taxonomy.

\section{New species}

Incisitermes peritus sp. n., Glyptotermes paleoliberatus sp. n., G. grimaldii sp. n., Cryptotermes glaesarius sp. n. 


\section{Introduction}

The termite family Kalotermitidae, or drywood termites, is one of the more primitive modern lineages of Isoptera, occurring throughout the world and with a standing diversity of approximately 487 species (living and fossil) and four subspecies. Members of the family establish colonies in relatively sound, damp or even dry wood (hence their label), and excavate a series of interconnected galleries rather than a clearly defined nest. Kalotermitid fossils are remarkably well known, with various species documented from Tertiary deposits throughout Europe and North America, as well as a few Cretaceous species from Asia (e.g., Williams, 1968; Engel et al., 2007a). In addition, putative trace fossils of kalotermitids have been reported from the Late Cretaceous of Argentina (Genise, 1995).

The drywood termites in Dominican amber are, not surprisingly, similar to the modern West Indian fauna, including species of Cryptotermes, Glyptotermes, and Incisitermes (the modern fauna also includes Neotermes and Procryptotermes) (Krishna \& Bacchus, 1987; herein) (Figs 1-3). The present contribution is part of a series designed to monograph the Tertiary amber termite fauna (e. g., ENGEL \& KRISHNA, in press; ENGEL et al., 2007b). The classification and format for descriptions followed herein are those of Krishna (1961) and Krishna \& BaCchus (1987). All measurements are provided in table 1 .

\section{Systematic Paleontology}

\section{Genus Incisitermes KRISHNA}

The genus Incisitermes was established by Krishna (1961) for 25 species distributed in the Nearctic and Neotropical regions, as well as in Southeast Asia and Oceanic islands. A single fossil species, Incisitermes krishnai EMERson in Mexican amber, is known for the genus. Herein we newly record the genus from Dominican amber. Not surprisingly, the species of Incisitermes in Dominican amber is similar to I. krishnai (vide Appendix). While imagoes in Dominican amber exhibit the same distinctive pronotal shape, wing venation, and distinctly swollen anterior margin to the wing scale, they differ in body proportions (metrics for the holotype and paratype of I. krishnai are provided in EMERson, 1969) and are, therefore, segregated into a separate, new species.

\section{Incisitermes peritus, sp. n. (Fig. 1)}

\section{Diagnosis:}

The new species is most similar to I. krishnai in Mexican amber (see appendix) but can be distinguished by the less transverse postclypeus (length/width in the new species $0.13 / 0.45$ versus $0.06 / 0.52$ in 1. krishnai); the longer forewings $(6.78-7.07 \mathrm{~mm}$ in the new species versus 5.85-5.60 $\mathrm{mm}$ in I. krishnai); the shorter head length (as measured from posterior margin to apical margin of the postclypeus $0.86-1.07 \mathrm{~mm}$ in the new species versus $1.22 \mathrm{~mm}$ in I. krishnai); the sparse setae of the head; indistinct Y-shaped coronal ecdysial cleavage line; second and third antennal articles each longer than fourth (second and third subequal to fourth in I. krishnai); and CuA with fewer primary branches. 


\section{Description:}

Imago. Head dark brown, pronotum brown (distinctly lighter than head), integument imbricate; antennae and legs brown. Head and pronotum very sparsely setose, nearly bare, setae fine and short, pronotum with a few long, fine setae on lateral margins; costal margin of wing scale with a few, short, fine setae, surface of scale nearly bare. Lateral margins of head subparallel, posterior margin evenly rounded; Y-shaped coronal ecdysial cleavage line not distinct; compound eye rounded, small, in lateral aspect well separated from posterior border of head, separated by distance more than compound eye length; ocellus oval, touching compound eye; anteclypeus subtrapezoidal, apical margin straight; postclypeus not demarcated; antenna with 16-17 articles; first article longest; second and third articles approximately equal in size, cylindrical, each longer than fourth article; remaining articles bead-like (as determined from the right antenna, the left antenna has some basal compression and distortion such that the basal articles appear differently proportioned). Pronotum wider than head, including compound eyes; anterior margin concave; lateral margins subparallel, faintly curved; posterolateral corners rounded, posterior margin relatively straight, medially faintly concave. Tibial spur formula 3-3-3; arolium present. Forewing membrane hyaline, densely nodulose, nodules not pigmented; Rs with 5-6 branches; M running approximately equidistant from $\mathrm{Rs}$ and $\mathrm{CuA}$; $\mathrm{CuA}$ with 7-8 primary branches.

\section{Holotype:}

Imago (Fig. 1), DR-8-340, Early Miocene (Burdigalian) amber, Dominican Republic (specific mine unknown).

\section{Paratypes:}

Four paratype imagoes, DR-10-1558, DR-10-1531, DR-2-22, and PB-273, Early Miocene (Burdigalian) amber, Dominican Republic (specific mine unknown). All specimens deposited in the Amber Fossil Collection, Division of Invertebrate Zoology, American Museum of Natural History, New York.

\section{Etymology:}

The specific epithet is based on the Latin term peritus, meaning "perished".

\section{Genus Glyptotermes FroggatT}

The genus Glyptotermes is a relatively common group of principally tropical drywood termites. With 22 described species from the neotropics (130 total for the world), Glyptotermes is one of the more diverse lineages of Kalotermitidae in the New World. Like all kalotermitids, species of Glyptotermes live and breed in the dry wood of dead trees and, as a result, some species can be pestiferous.

To date a single fossil species of Glyptotermes has been described, Termes pusillus (transferred to Glyptotermes by Rosen, 1913) by Heer (1849) from what he believed to be Tertiary amber but which was actually African copal of Pleistocene origin. The genus has also been recorded but never formally described from Early Miocene amber of the Dominican Republic (Scheffrahn et al., 2003). The Dominican amber fauna of Glyptotermes includes two species and mirrors the modern West Indian fauna. Today Glyptotermes liberatus (SNYDER) and G. pubescens SNYDER can be found sympatrically in the West Indies and differ (as imagoes) in basically the same features that separate the two fossil species. Glyptotermes liberatus is a larger species, with dark integument, pigmented nodulations on the wings, and noticeably granulose integumental sculpturing on the 
head capsule. In contrast, $G$. pubescens is a smaller species, with reddish brown integument, hyaline wings, and a smooth head. This same pattern of differences can similarly serve to differentiate the fossil species, although the larger fossil species differs from the modern $G$. liberatus in that, aside from the wing nodule apices, the wing membrane is hyaline while in the living species the wings are semi-opaque and distinctly infuscate. The fossil analog of $G$. pubescens is also a lighter species, with a light brown integument, hyaline wings inclusive of the nodulations, and a less strongly sculptured head capsule. However, the smaller and lighter fossil does not have the glabrous head integument of $G$. pubescens, instead exhibiting a faint imbrication throughout its surface.

\section{Glyptotermes paleoliberatus, sp. n. (Figs 3-4)}

\section{Diagnosis:}

The fossil differs from $G$. liberatus in that the wing membrane is hyaline except for the nodule apices (infuscate in the modern species) and the Y-shaped coronal lines are complete (coronal lines only evident as a single line posteriorly in the modern species). Glyptotermes paleoliberatus differs from the only other Glyptotermes present in Dominican amber, G. grimaldii (vide infra), in its larger size; black integument; granulose head capsule; second antennal article distinctly longer than the individual lengths of the third and fourth articles; and pigmented apices to the nodulations of the wing membrane.

\section{Description:}

Imago. Head and pronotum black (Figs 3-4), integument of head granulose; antennae dark brown, legs light brown. Head and pronotum with widely scattered, fine, short setae; costal margin of wing scale without setae, surface of scale with a few fine, short setae. Lateral margins of head subparallel, posterior margin evenly rounded; Y-shaped coronal ecdysial cleavage line complete but faint; compound eye rounded, small, in lateral aspect separated from posterior border of head by distance greater than compound eye length; ocellus touching compound eye; anteclypeus subtrapezoidal, apical margin straight; postclypeus not demarcated; antenna with 12-14 articles; first article slightly shorter than second article; second article longer than individual lengths of second and third articles; second and third articles approximately equal in length, slightly transverse. Pronotum as wide as head; anterior margin shallowly concave; lateral margins gently and evenly curved, subparallel; posterolateral corners broadly rounded, posterior margin evenly rounded. Tibial spur formula 3-3-3; arolium present. Forewing membrane hyaline, with numerous pigmented nodulations (Fig. 4).

\section{Holotype:}

Imago (Fig. 3), DR-14-647, Early Miocene (Burdigalian) amber, Dominican Republic (specific mine unknown).

\section{Paratypes:}

Six paratype imagoes, DR-8-335, DR-10-1545, DR-14-647, DR-10-1516, DR-10-1251, and PB-272, Early Miocene (Burdigalian) amber, Dominican Republic (specific mine unknown). All specimens deposited in the Amber Fossil Collection, Division of Invertebrate Zoology, American Museum of Natural History, New York.

\section{Etymology:}

The specific epithet is a reference to this species being the fossil analog of G. liberatus in the West Indian fauna. 


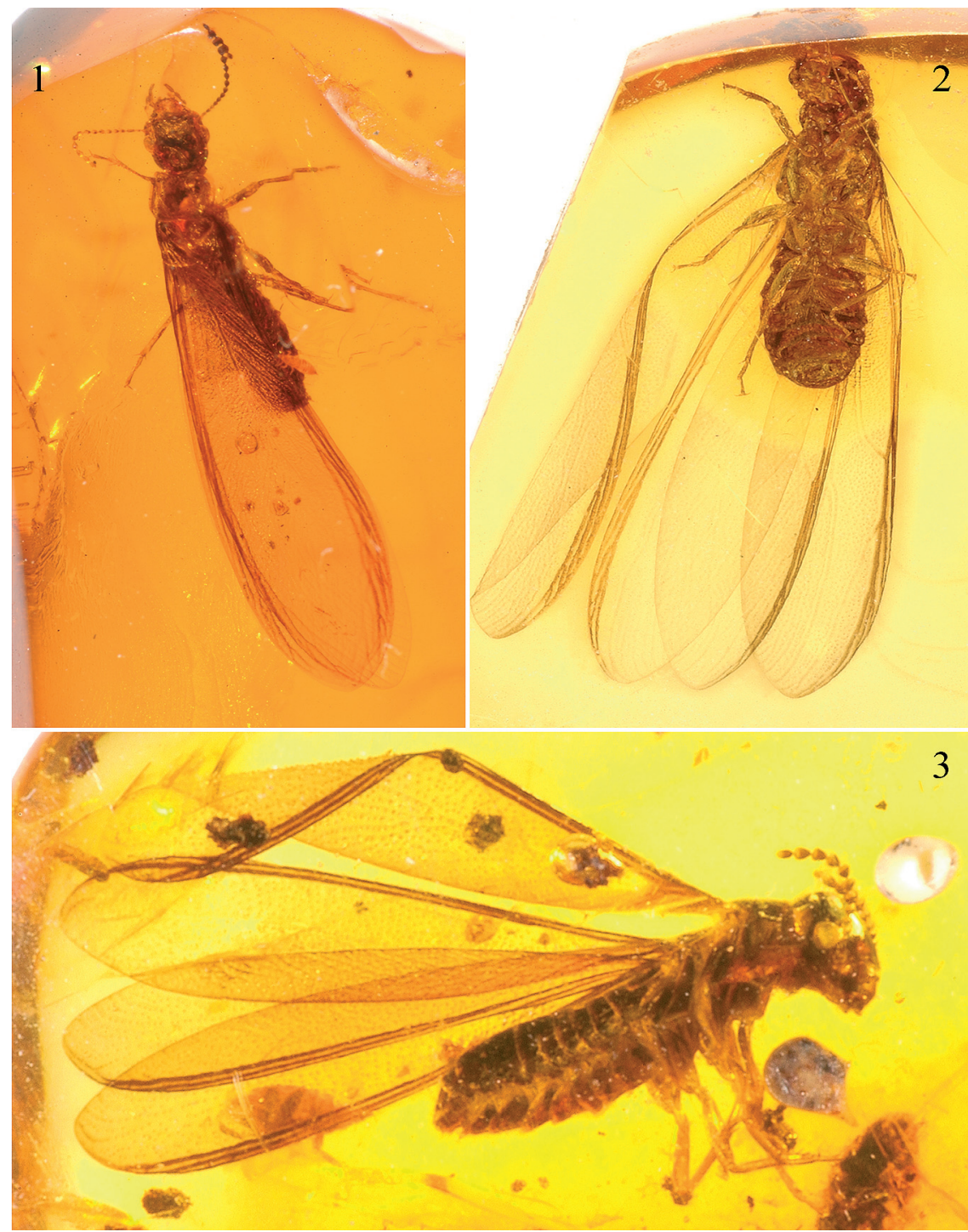

Figs 1-3: Photomicrographs of genera of Dominican amber Kalotermitidae (Isoptera). 1 Holotype imago of Incisitermes peritus sp. n. (DR-8-340). - 2 Holotype imago of Cryptotermes glaesarius sp. n. (AMNH, no acc. no.). - 3 Holotype imago of Glyptotermes paleoliberatus sp. n. (DR-14-647).

\section{Glyptotermes grimaldii, sp. n. (Fig. 5)}

\section{Diagnosis:}

This species can be differentiated from $G$. paleoliberatus (vide supra) by its smaller size; light brown integument; faintly imbricate sculpturing on the head capsule; second, third, and fourth antennal articles being subequal in length (the second antennal article is distinctly longer than the individual lengths of the third and fourth articles in modern species and in G. paleoliberatus); 

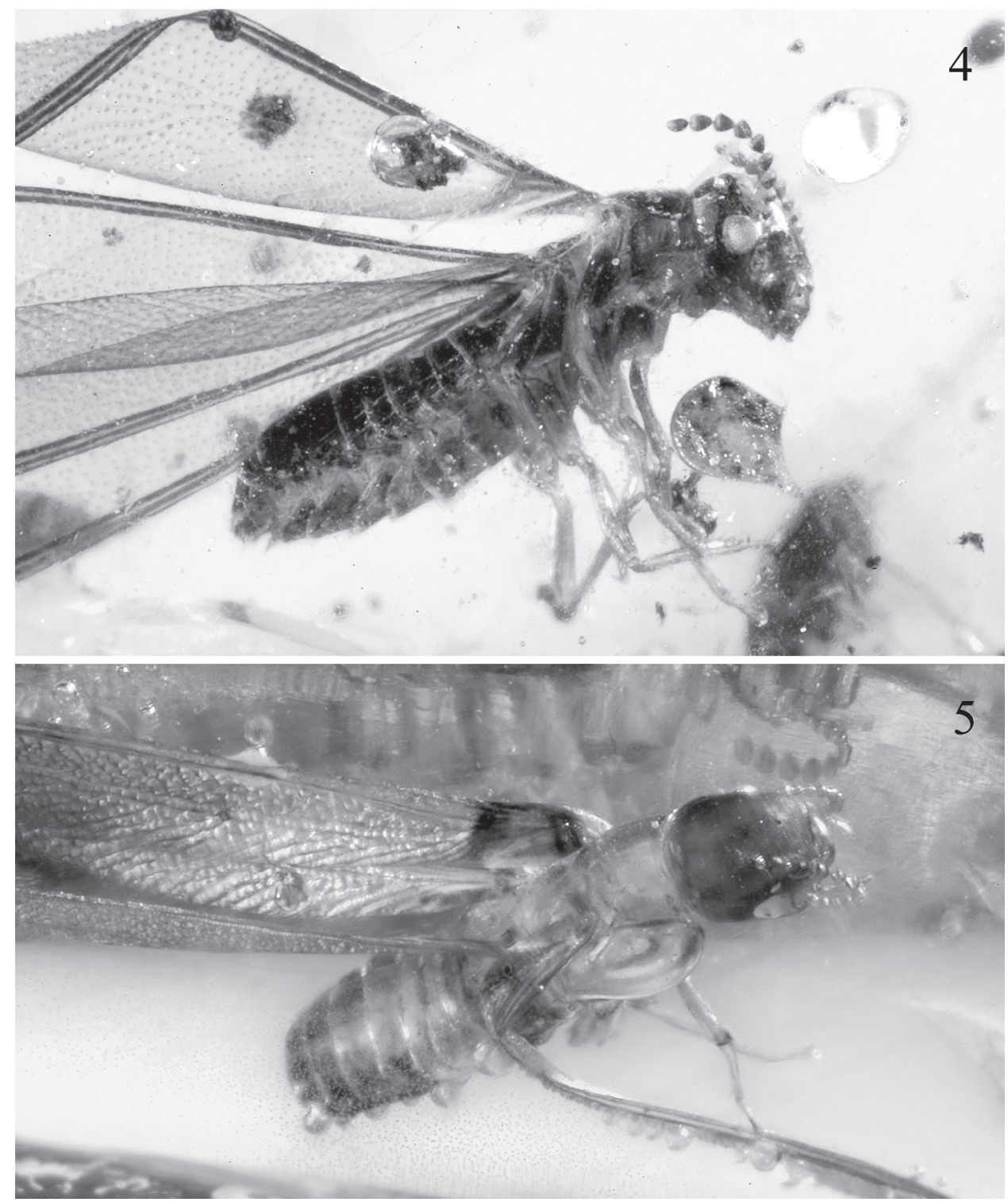

Figs 4-5: Photomicrographs of holotype imagoes for Dominican amber Glyptotermes. - 4 Glyptotermes paleoliberatus sp. n. (DR-14-647). - 5 Glyptotermes grimaldii sp. n. (DR-10-1505).

and completely hyaline nodule apices. In most of these features the fossil resembles modern $G$. pubescens but that species has a distinctly glabrous integument and the typical proportions of the basal antennal articles.

\section{Description:}

Imago. Head and pronotum light brown, integument faintly imbricate; antennae and legs light yellowish brown. Head and pronotum with widely scattered, fine, short setae; costal margin of wing scale without setae, surface of scale with a few fine, short setae. Lateral margins of head subparallel, 
posterior margin evenly rounded; Y-shaped coronal ecdysial cleavage line faint; compound eye rounded, small, in lateral aspect separated from posterior border of head by distance greater than compound eye length; ocellus touching compound eye; anteclypeus subtrapezoidal, apical margin straight; postclypeus not demarcated; antenna with $12+$ articles (perhaps incomplete); first article slightly longer than second article; second, third, and fourth antennal articles subequal in length. Pronotum slightly narrower than head; anterior margin concave; lateral margins gently and evenly curved, subparallel; posterolateral corners broadly rounded, posterior margin evenly rounded. Tibial spur formula 3-3-3; arolium present. Forewing membrane hyaline, with numerous nodulations, nodules not pigmented.

\section{Holotype:}

Imago (Fig. 5), DR-10-1505, Early Miocene (Burdigalian) amber, Dominican Republic (specific mine unknown). Deposited in the Amber Fossil Collection, Division of Invertebrate Zoology, American Museum of Natural History, New York.

\section{Etymology:}

The specific epithet is a patronymic honoring Dr. David A. Grimaldi, close friend and colleague, and leading expert on insect systematics, evolution, and paleontology, as well as the world's authority on amber and its inclusions.

\section{Genus Cryptotermes Banks}

The genus Cryptotermes is a principally pantropical lineage of drywood termites, with a few species extending into warm temperate regions excluding the Palearctic. Like other kalotermitids, the genus breeds in dry portions of dead timber, making it an ideal candidate for dispersal by humans. Indeed, several Cryptotermes species, such as C. dudleyi BANKs and C. brevis (WALKER), have been widely introduced and are notable pests.

Three fossils have been recorded in the genus Cryptotermes. The first was C. batheri (Rosen), listed as occurring in Pleistocene copal from East Africa (Rosen, 1913) but unfortunately never formally described and, as such, the species name is a nomen nudum. This name was subsequently transferred to Mastotermes and for a fossil from the Oligocene deposits of Rott, Germany (STATZ, 1939). Clearly, the status of this taxon is in need of clarification. Cryptotermes ryshkoffi PIERCE was described from an imago preserved in Miocene nodules from the Calico Mountains of southern California (PierCE, 1958). The last species, Cryptotermes yamini, was described from a single imago in Dominican amber (Fig. 7; Krishna \& Bacchus, 1987). Since the late 1980s numerous individuals of Cryptotermes in Dominican amber have been acquired and while many of these are additional specimens of C. yamini, a second, quite similar species has also been discovered among them (Fig. 2).

\section{Cryptotermes glaesarius, sp. n. (Figs 2, 6)}

\section{Diagnosis:}

The new species appears most similar to C. yamini, also in Dominican amber. The species differs from the latter, however, by the concave anterior margin of the anteclypeus (straight in C. yamini), the larger number of antennal articles (16-18 versus 14 in C. yamini), the joining of $\mathrm{M}$ into Rs near the wing midlength ( $\mathrm{M}$ joining Rs beyond wing midlength in $C$. yamini), and the overall larger body proportions (Table 1). 


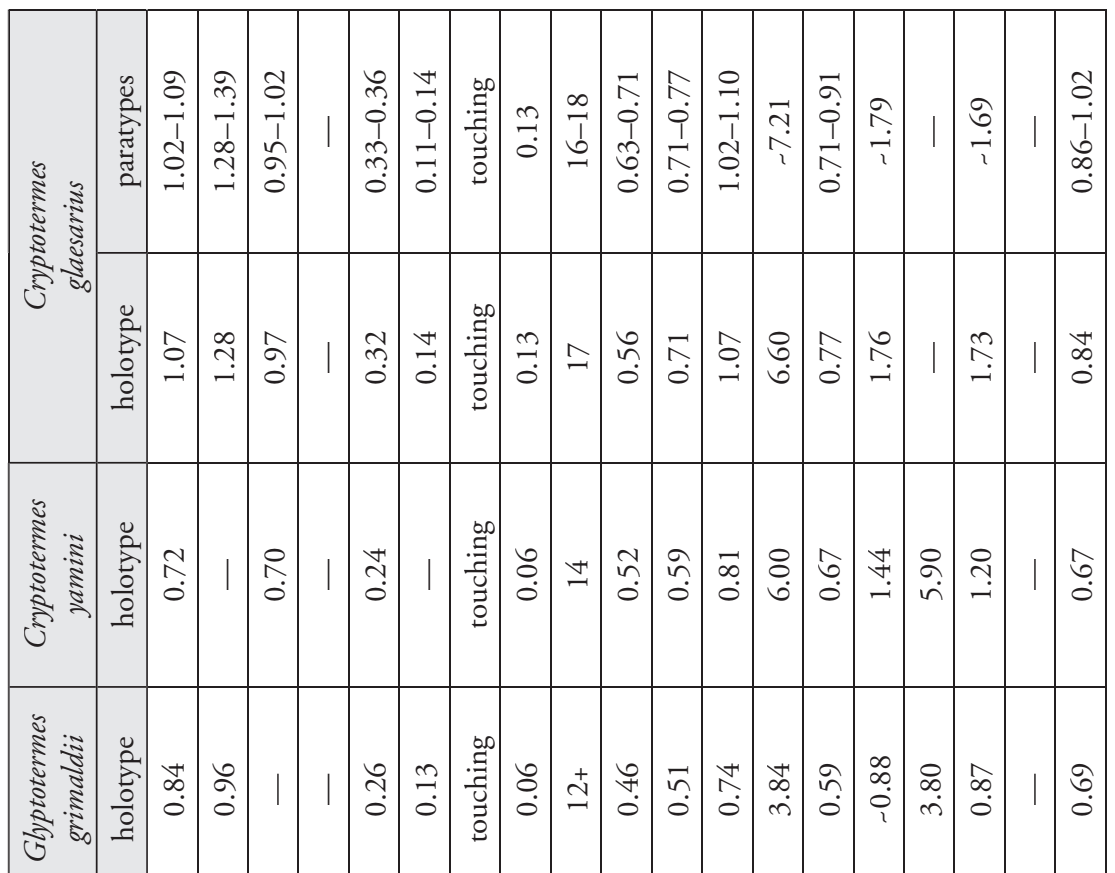

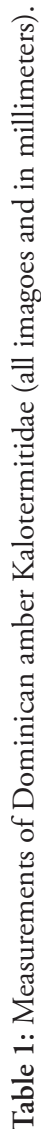

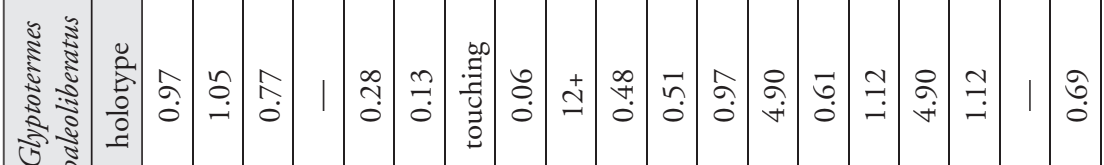

\begin{tabular}{|c|c|c|c|c|c|c|c|c|c|c|c|c|c|c|c|c|c|c|c|c|}
\hline 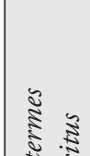 & 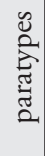 & $\hat{\sigma}$ & 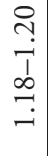 & | & 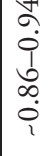 & 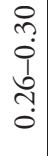 & 1 & 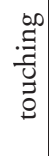 & $\begin{array}{l}\infty \\
0 \\
0 \\
0\end{array}$ & $\begin{array}{c}\curvearrowright \\
\vec{b} \\
\end{array}$ & $\begin{array}{l}\vec{n} \\
\tilde{0} \\
1 \\
0 \\
\tilde{o}\end{array}$ & $\begin{array}{l}0 \\
0 \\
0 \\
1 \\
0 \\
0 \\
0 \\
1\end{array}$ & $\left|\begin{array}{c}0 \\
0 \\
-1 \\
\tilde{J} \\
\tilde{0} \\
-i \\
i\end{array}\right|$ & 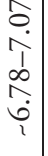 & $\begin{array}{l}\tilde{b} \\
\dot{0}\end{array}$ & $\underset{\sim}{\stackrel{a}{i}}$ & | & | & 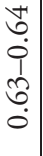 & 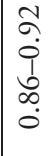 \\
\hline & 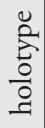 & סै & $\begin{array}{c}\infty \\
\stackrel{\infty}{-}\end{array}$ & | & $\stackrel{\hat{i}}{ }$ & $\bar{n}$ & 1 & 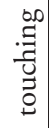 & $\begin{array}{l}\infty \\
0 \\
0 \\
0\end{array}$ & $\stackrel{0}{\circ}$ & $\hat{\widehat{0}}$ & $\begin{array}{l}\infty \\
\infty \\
0\end{array}$ & $\mid \begin{array}{l}\hat{\theta} \\
- \\
-\end{array}$ & $\hat{\sigma}$ & 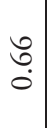 & $\begin{array}{l}\stackrel{a}{0} \\
\text { ì }\end{array}$ & 1 & | & $\begin{array}{l}\tilde{b} \\
0 \\
0\end{array}$ & $\hat{\sigma}$ \\
\hline
\end{tabular}

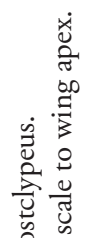
峞

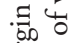

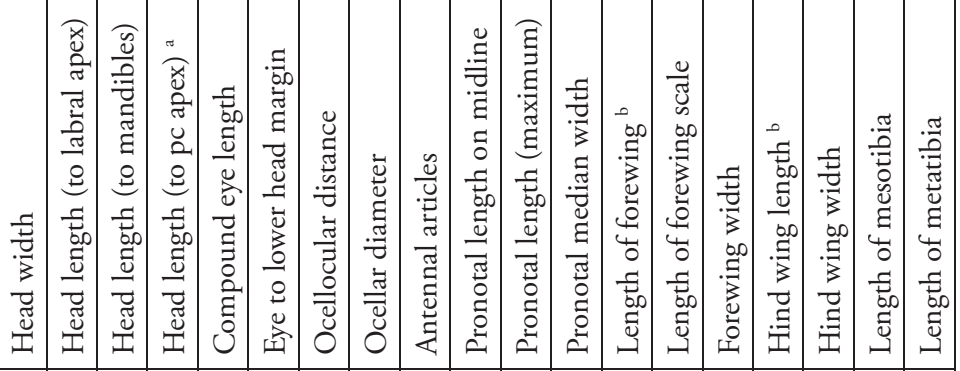

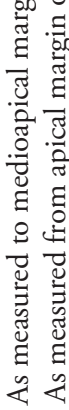



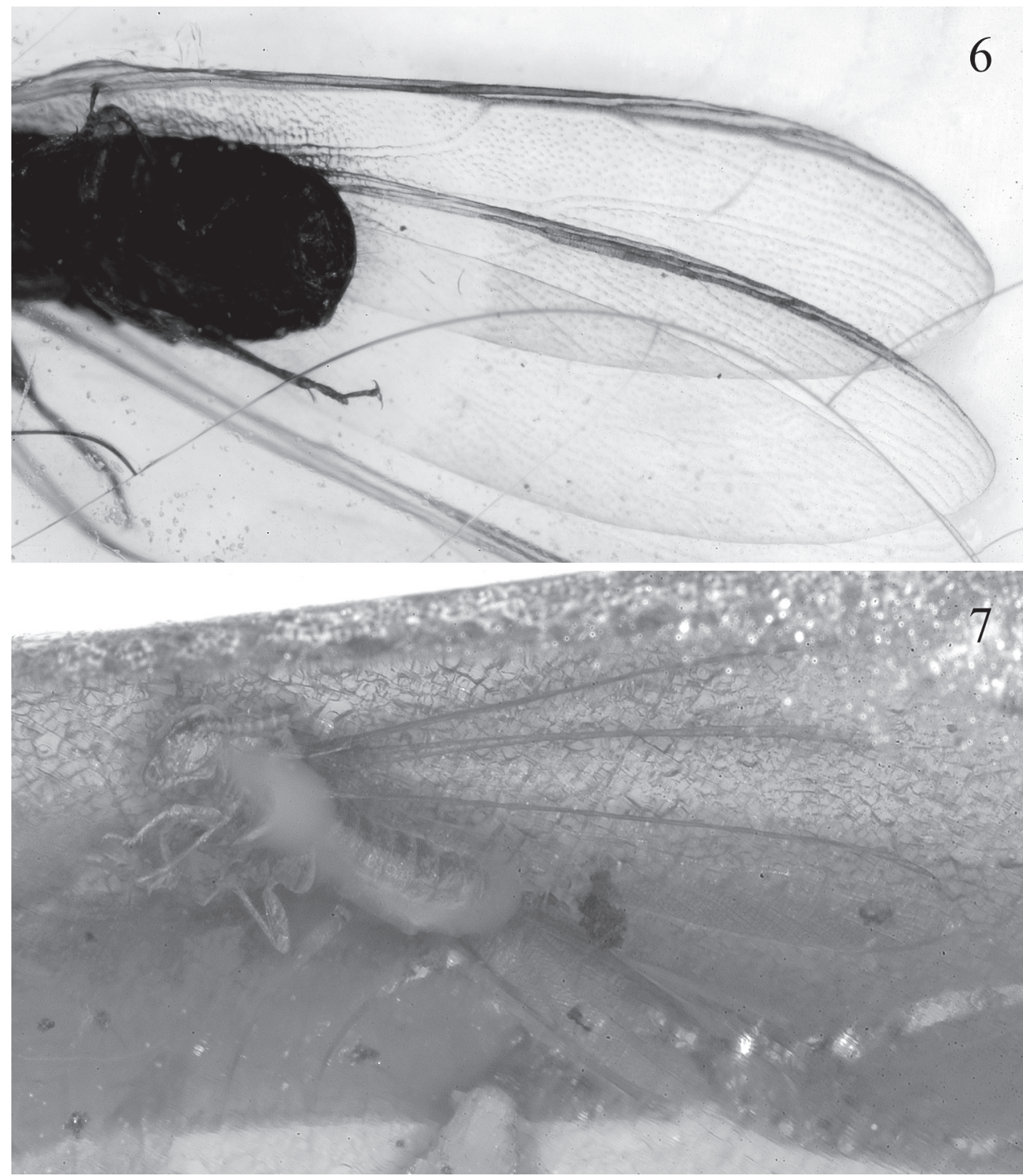

Figs 6-7: Photomicrographs of holotype imagoes for Dominican amber Cryptotermes. - 6 Detail of forewing venation of Cryptotermes glaesarius sp. n. (AMNH, no acc. no.). - 7 C. yamini KrIsHNA \& BACCHus.

\section{Description:}

Imago. Head and pronotum brown (Fig. 2), integument glabrous; antennae and legs yellowish brown. Head and pronotum very sparsely setose, nearly bare, setae fine and short; costal margin of wing scale with a few, short, fine setae, surface of scale nearly bare. Lateral margins of head subparallel, posterior margin evenly rounded; Y-shaped coronal ecdysial cleavage line distinct; compound eye rounded, of moderate size, in lateral aspect separated from posterior border of head by distance approximately equal to compound eye length; ocellus oval, touching compound eye; anteclypeus subtrapezoidal, apical margin concave; postclypeus not demarcated; antenna with 
16-18 articles; first article longest, approximately 1.5 times longer than wide; second and third articles approximately equal in size, each longer than fourth article. Pronotum wider than head, including compound eyes; anterior margin concave; lateral margins gently and evenly curved, subparallel; posterolateral corners broadly rounded, posterior margin shallowly concave medially. Tibial spur formula 3-3-3; arolium present. Forewing membrane hyaline, with weak papillae, such papillae generally not pigmented; Rs with six branches; $M$ joining Rs near wing midlength (Fig. 6).

\section{Holotype:}

Imago, no accession number, Early Miocene (Burdigalian) amber, Dominican Republic (specific mine unknown).

\section{Paratypes:}

Three paratype imagoes, DR-10-1503, DR-10-1534, last without accession number, Early Miocene (Burdigalian) amber, Dominican Republic (specific mine unknown). Deposited in the Amber Fossil Collection, Division of Invertebrate Zoology, American Museum of Natural History, New York.

\section{Additional material:}

Ten imagoes, DR-8-342, DR-10-1506, DR-10-1524, DR-10-1511, PB-271, PB-275, DR-10-1515, DR-10-1264, DR-10-1677, DR-10-1507, Early Miocene (Burdigalian) amber, Dominican Republic (specific mine unknown). Deposited in the Amber Fossil Collection, Division of Invertebrate Zoology, American Museum of Natural History, New York.

\section{Etymology:}

The specific epithet is the Latin term glaesarius, meaning "of amber."

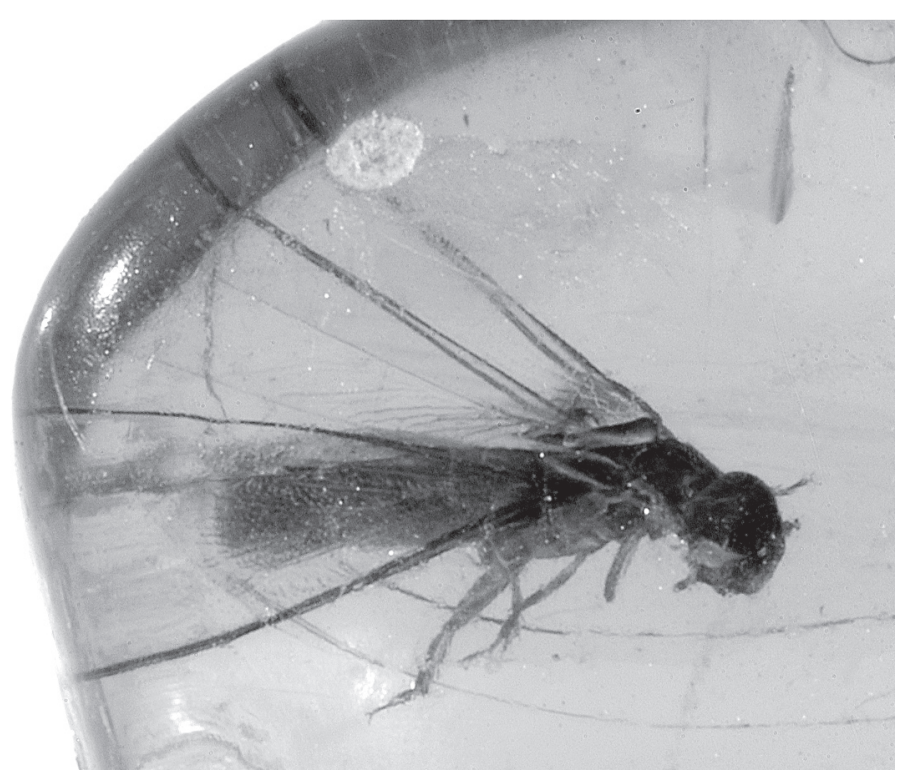

Fig. 8: Photomicrograph of new specimen of Cryptotermes yamini KRISHNA \& BACCHUS (DR-8-339). 


\section{Cryptotermes yamini KRISHNA \& BACCHUS (Figs 7-8)}

Cryptotermes yamini KRISHNA \& BACCHUS, 1987: 2.

\section{Diagnosis:}

Refer to diagnosis provided for C. glaesarius (vide supra) and Krishna \& BACCHUs (1987).

\section{Holotype:}

Imago (Fig. 7), Early Miocene (Burdigalian) amber, Dominican Republic (specific mine unknown). Deposited in the Amber Fossil Collection, Division of Invertebrate Zoology, American Museum of Natural History, New York.

\section{New material:}

Four imagoes, DR-10-1616, DR-8-339 (Fig. 8), DR-10-1672, DR-10-1517, and four additional imagoes without accession numbers, Early Miocene (Burdigalian) amber, Dominican Republic (specific mine unknown). Deposited in the Amber Fossil Collection, Division of Invertebrate Zoology, American Museum of Natural History, New York.

\section{Acknowledgements}

We are grateful to David HaAsL (University of California, Berkeley, Museum of Paleontology) for the loan of EMERSON's type material; to Ismael A. Hinojosa-Díaz for translating our abstract into Spanish; and to Valerie KRISHNA for carefully reading the manuscript. Support was provided by National Science Foundation grant DEB-0542909 and a Guggenheim Fellowship from the John Simon Guggenheim Memorial Foundation (both to M.S. EnGEL). This is contribution No. 3472 of the Division of Entomology, University of Kansas Natural History Museum.

\section{References}

Emerson, A. E. 1969: A revision of the Tertiary fossil species of the Kalotermitidae (Isoptera). - American Museum Novitates 2359: 1-57.

Engel, M. S. \& Krishna, K. In press: New Dolichorhinotermes from Ecuador and in Mexican amber (Isoptera: Rhinotermitidae). - American Museum Novitates.

Engel, M. S.; Grimaldi, D. A. \& Krishna, K. 2007a: Primitive termites from the Early Cretaceous of Asia (Isoptera). - Stuttgarter Beiträge zur Naturkunde, Serie B, Geologie und Paläontologie 371: 1-32.

Engel, M. S.; Grimaldi, D. A. \& Krishna, K. 2007b: A synopsis of Baltic amber termites (Isoptera). - Stuttgarter Beiträge zur Naturkunde, Serie B, Geologie und Paläontologie 372: 1-20.

Genise, J. F. 1995: Upper Cretaceous trace fossils in permineralized plant remains from Patagonia, Argentina. - Ichnos 3: 287-299.

Heer, O. 1849: Die Insektenfauna der Tertiärgebilde von Oeningen und von Radoboj in Croatien: Zweiter Theil: Heuschrecken, Florfliegen, Aderflügler, Schmetterlinge und Fliegen. - Pp. iv+264 - Leipzig: W. Engelmann.

KRISHNA, K. 1961: A generic revision and phylogenetic study of the family Kalotermitidae (Isoptera). Bulletin of the American Museum of Natural History 122 (4): 303-408.

Krishna, K. \& Bacchus, S. 1987: A new fossil species of termite from Dominican amber, Cryptotermes yamini (Isoptera, Kalotermitidae). - American Museum Novitates 2884: 1-5.

Pierce, W. D. 1958: Fossil arthropods of California, No. 21: Termites from Calico Mountains nodules. Bulletin of the Southern California Academy of Sciences 57 (1): 13-24.

Rosen, K. von 1913: Die fossilen Termiten: Eine kurze Zusammenfassung der bis jetzt bekannten Funde. In Jordan, K. \& Eltringham, H. (editors), Transactions of the $2^{\text {nd }}$ International Congress of Entomology [volume II]. - London: Hazell, Watson, and Viney: 318-335. 
Scheffrahn, R. H.; Jones, S. C.; Krecek, J.; Chase, J. A.; Mangold, J. R. \& Su, N.-Y. 2003: Taxonomy, distribution, and notes on the termites (Isoptera: Kalotermitidae, Rhinotermitidae, Termitidae) of Puerto Rico and the U.S. Virgin Islands. - Annals of the Entomological Society of America 96 (3): 181-203.

SNYDER, T. E. 1960: Fossil termites from Tertiary amber of Chiapas, México. - Journal of Paleontology 34: 493-494.

Statz, G. 1939: Geradflügler und Wasserkäfer der Oligocänen Ablagerungen von Rott. - Decheniana 99A: $1-104$.

Williams, R.M.C. 1968: Redescriptions of two termites from Burmese amber. - Journal of Natural History 2: $547-551$.

\section{Appendix}

\section{Re-examination of Incisitermes krishnai EMERSON}

In connection with our revision of the Dominican amber drywood termite fauna we examined the type material of some of those species previously described from the roughly contemporaneous Mexican amber. We were particularly interested in Incisitermes krishnai EMERSON, as material of the other Mexican species was already available and had been studied. Through the kindness of David HaAsL, University of California Museum of Paleontology, we were able to study EMERson's type material as preserved in that institution. The holotype of $I$. krishnai is in excellent condition and shows many important details (Fig. 9). Herein we provide a new description and for the first time photographs of this species (Figs 9-10) to supplement the sketches provided by EMERson (1969). The following account is based on our November 2006 examination of the holotype and paratype.

\section{Incisitermes krishnai EMERSON (Figs 9-10)}

“Kalotermes nigritus SNYDER": SNYDER, 1960: 493. Misidentification. Incisitermes krishnai EMERson, 1969: 46.

\section{Description:}

For holotype (Figs 9-10) except as noted: Imago. Head and pronotum brown, integument faintly imbricate; antennae and legs light brown. Head and pronotum with numerous fine, short setae, pronotum with a few long, fine setae on disc and lateral margins; costal margin and surface of wing scale with numerous fine, short setae; abdomen with sparse erect to suberect (mostly erect on terga), short to moderate-length setae. Postclypeus transverse, short and wide. Dentition (only visible in paratype) of left mandible scarcely visible, first and second marginal teeth appearing slightly shorter than third marginal tooth; cutting edge of first and second marginal teeth slightly concave. Lateral margins of head subparallel, posterior margin evenly rounded; Y-shaped coronal ecdysial cleavage distinct; compound eye rounded, small, in lateral aspect well separated from posterior border of head, separated by distance more than compound eye length; ocellus oval, touching compound eye; anteclypeus subtrapezoidal, apical margin straight; postclypeus not demarcated; antenna with 17 articles; first article longest; second through fourth articles approximately equal in size. Pronotum wider than head, including compound eyes; anterior margin concave; lateral margins subparallel, faintly curved; posterolateral corners converging, posterior margin relatively straight, medially faintly concave. Tibial spur formula 3-3-3; arolium present. Forewing membrane hyaline, densely nodulose, nodules not pigmented; Rs with 4-5 branches; $\mathrm{M}$ running approximately equidistant from $\mathrm{Rs}$ and $\mathrm{CuA}$; $\mathrm{CuA}$ with 10-11 primary branches. 

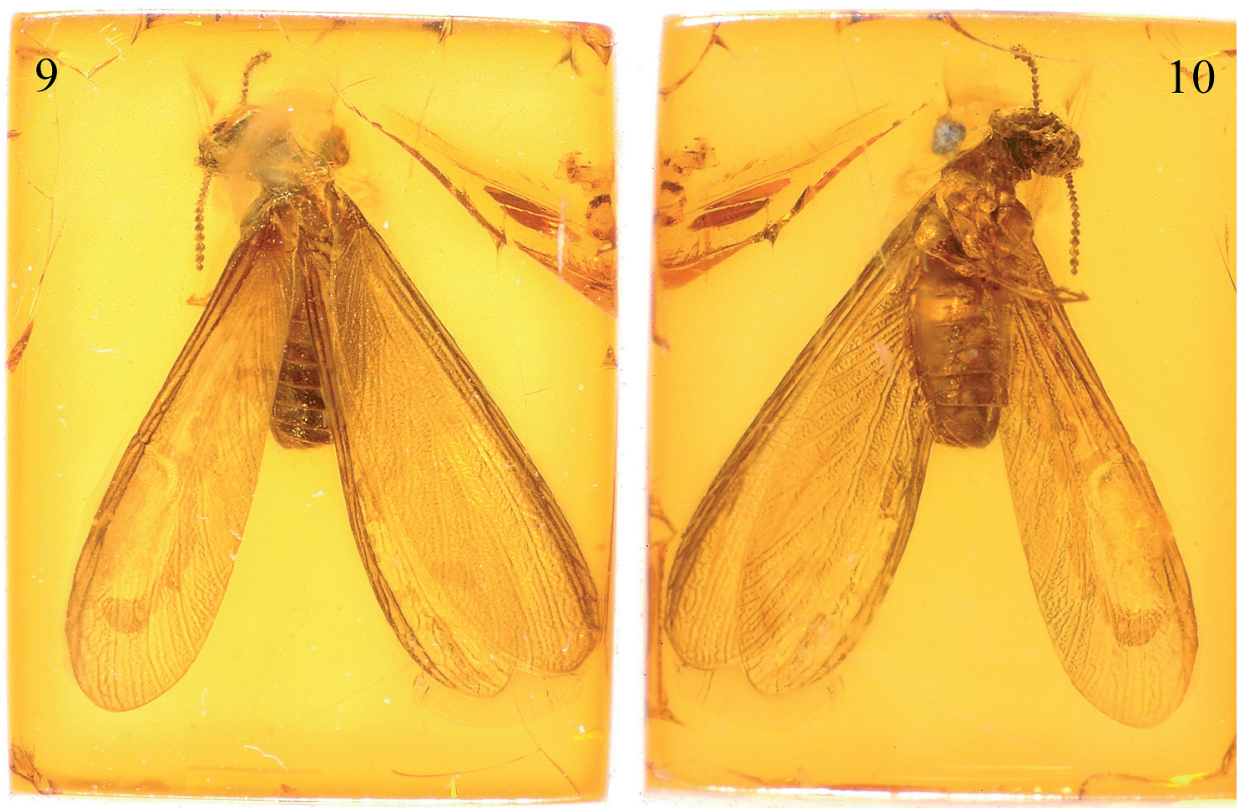

Figs 9-10: Photomicrographs of holotype imago of Incisitermes krishnai EMERSON (UCMP 12613).

-9 Dorsal aspect. - 10 Ventral aspect.

\section{Measurements:}

Refer to EMERson (1969) for measurements of the holotype and paratype.

\section{Holotype:}

Imago (Figs 9-10), UCMP 12613, amber, Mexico, Chiapas, Las Cruces. Deposited in the Department of Invertebrate Paleontology, University of California Museum of Paleontology, Berkeley, California.

\section{Paratype:}

Imago, UCMP 12945, same collection data and repository as holotype.

\section{Authors' address:}

Prof. Dr. M. S. EngeL

Division of Entomology (Paleoentomology)

Natural History Museum

1501 Crestline Drive, Suite 140

University of Kansas

Lawrence, Kansas 66049-2811

United States
Dr. K. KRISHNA

Division of Invertebrate Zoölogy

American Museum

of Natural History

Central Park West at $79^{\text {th }}$ Street

New York, New York 10024-5192

United States

\section{Subject editor:}

Prof. Dr. W. Wichard 